\title{
Job Burnout and Thriving in Chinese Public Sector
}

\author{
Hou Longlong
}

\begin{abstract}
Chinese public sector is a very large hierarchy system. Many employees in public sector haven't higher identification and belongings, and this paper is trying to discuss and solve this problem. This paper suggests the job thriving from the positive psychology perspective, and as a way to overcome the job burnout; and analyzes the occupation strength as one important element of occupation thriving.
\end{abstract}

Index Terms-Job burnout, job thriving, Chinese public sector.

\section{INTRODUCTION}

Chinese public sector is a very large hierarchy system. It includes not only the central and local government employees but also those affiliated public institutions and enterprises such as schools, hospitals, banks, trade associations etc.... The institution which the writer of this paper belongs to is a public research university, also a typical public sector. The writer has interviewed several colleagues recently; I ask them like "Do you wish your children will do the same occupation like you in the future?" This question is designed like this: seemingly we ask the respondents' job expectation on their children. Actually, we want to investigate their job satisfaction, identification and belonging The relationship is like this: if the respondent has higher identification and belonging to his/her job, and gain job satisfaction, then he/she is more likely to expect his/her children to engage in the same occupation. So, through this indirect way we could get the respondents' real ideas about the identification and belonging to their jobs. Of course, we could also directly ask the respondents "do you have higher identification and belongings to your job?. Whether strangers or colleagues the respondents are, we don't think they will tell the real answer. So we adopt this indirect circuitous way to interview them. Except for several colleagues give the positive answer, these colleagues, based on my personal observation, usually performed very well at work, and have extraordinarily teaching performance. Most people give the negative response. When I ask why, answers mainly focus on "high pressure, and low income". US scholars Rumbley, Pacheco, and Altbach have made a 28 cross countries survey; Chinese college teachers who have just entered the job earn the least salaries among those countries, which is about 259 US dollars per month adjusted through PPP (purchasing power parity) [1]. Maybe this is an only accidental finding.

After that, the writer made two investigations in two different public sectors. The first one is a tax department in Beijing; in April this year we ask about 50 managerial

Manuscript received August 15, 2013; revised November 10, 2013.

Hou Longlong is with the Beijing Normal University, P. R. China (e-mail: 76618967@qq.com). personnel the same question "Do you wish your children will do the same occupation like you in the future?", about $80 \%$ of the respondents made the negative answer, and some made no answers. When ask why, it's same like "high pressure, and low income". The second survey is done on April 11 this year. 50 core teachers from primary schools in Dandong city Liaoning province are asked the same question. Except for 2 teachers, others gave the negative answer, and when ask why; it is also same like above.

Through these two investigations and one interview we find that there are problems in the salary system in Chinese public sector. Lower salary couldn't afford most of the living needs, and this forces the employees in public sector have to find other ways to increase their income. The reform of salary system in Chinese public sector is not the focal point of this paper; the writer will discuss it in another article. Another finding through these investigations is the job burnout in public sectors. Many employees in public sector haven't higher identification and belongings, and this paper is trying to discuss and solve this problem.

The rest of the paper consists of 7 parts: the Section II will review the literatures about job burnout in Chinese public sector. Section III \& IV suggests the job thriving from the positive psychology perspective, and as a way to overcome the job burnout; Section V, VI, \& VII analyzes the occupation strength as one important element of occupation thriving. Section VIII sums up.

\section{Literature Review: Job Burnout in Chinese PubliC SECTOR}

The following part will review the literatures about job burnout in Chinese public sector. Which papers have made and what findings we have known.

Wang weihua has made a survey on 339 government employees in Tianjin city in China, and found most of the respondents appeared medium degree of job burnout. And suggests improving the problem through personal, organizational and social level [2]. ZHANG Hong-xia and CUI Ning investigated 150 college teachers in Tianjin University of Science and Technology, and found the emotional exhaustion has appeared. They suggest relieving and preventing job burnout through social, university's and teacher's ways [3]. Pan xiaohua studied the job burnout of nurse, and recommended relieving it through organizational environment, social environment and personal ways [4].

To sum up, the above researches about job burnout in public sector in china suggest some methods to relieve the problems. These methods may make people who are burnout normal, but it won't unleash their potentials and make excellent performance.

In order not only to relieve job burnout, but unleash every 
employee's potentials, I suggest to solve this problem from both external position design and internal employee own.

\section{COPE WITH JOB BURNOUT FROM EXTERNAL: POSITION DESIGN}

According to Edward Lawler III's opinion, besides better relationship among colleagues and leader with subordinates, it is the position design which mostly influences the internal work motivation of employees [5]. As to the position design, it should have the following four important characters: (1) the autonomy of the position, whether or not the position of employees has autonomy, like whether or not the employee could decide in what way to finish the task on his own, whether or not the employee could decide the job content, and whether or not the employee could decide the job schedule, speed and process, and whether or not the employee could decide team member, whom to work with, will has great impact on employee's work motivation. (2) The diversity and richness of the job position, instead of dull and repeat, the former will make continuous new challenge for employee, and it requires new knowledge and skills to face. The latter causes tired of boring and job burnout. (3) The integrity of the job position. It means the job has obvious beginning and end, employee could feel the cycle of the task. Employee should not been arranged for endless task, no start and end. (4) The feedback of the job. It means the leader should give employee timely and necessary feedback, the leader should have impression on every employee and evaluate everyone's specific task.

Besides, the better relationship between colleagues and leader with subordinate is also very important for work motivation. These are methods when promotion and salary raise does not work.

\section{COPE WITH JOB BURNOUT FROM INTERNAL: JOB THRIVING IN POSITIVE PSYCHOLOGY PERSPECTIVE}

From the internal work motivation, Professor Martin Seligman believes that traditional psychology has put too much attention on psychological diseases, and less on how to fulfill people's potentials and make people work and live prosperously [6]. As to the job burnout, the writer believes we should take the same way. Many studies on job burnout could relieve the problem, but it won't unleash their potentials and make excellent performance. Following the thinking model of positive psychology, the writer believes that we should find the answer from the opposite side of job burnout, which ideas of job are thriving.

Firstly, let's take a look at positive organization behavior's some points about thriving. Spreitzer et al. suggest that vitality and learning are two essential components of thriving [7]. Vitality refers to the positive feeling of having energy available, reflecting feelings of aliveness. and learning means individual acquire knowledge and skills, meantime apply these knowledge and skills. So thriving registers the joint sense of vitality and learning, and it includes two sides, the affective factor of psychological experience and cognitive factor.
According to Spreitzer et al.'s definition of thriving, the writer believes that job thriving means learning with vitalityin some occupation. It is not thriving when someone has vitality without learning in his work. Likewise, either when someone learns without vitality. It is common employees learn without vitality in Chinese public sector. For example, there are lots of meetings in public sector to learn documents from superior government; it is common employees doze off, or play cell phone, absence of mindedness in these meetings.

Then how to make employees in public sector more vigorous? Generally, there are several ways: first, from individual level, you need to improve in body strength, emotional energy and cognitive activity. Then, the leader of the public sector should adopt democratic style, and it is helpful to fulfill the potentials of subordinates. Third, the character of the work should be designed as autonomy, completeness, feedback; the tasks needs diversified skills and should be valuable and meaningful. Last, trust and higher cohesion based on values could engender more job vitality.

\section{JOB STRENGTH AND THRIVING}

Besides job vitality and learning, the writer suggests job thriving has another important element, which is job strength. In order to achieve job thriving, from internal side it is necessary to learn with vitality; moreover from external side to exert the certain job strength for different jobs.

Job strength means comparing with other jobs what advantages specific job has. For example, teachers' strength is its working time freely, and about three months holiday, in China, there usually are one month winter holiday and two months summer holiday in primary schools, secondary schools and colleges etc... When analyzing the job strength, we will indicate the respondents write down three outstanding advantages comparing with other jobs. And then we will discuss together how to bring every advantage into play, with what methods, and what factors will hinder the play, how to overcome. For instance, teachers' strength is winter and summer holidays, if teachers continue to work instead of relaxing on holidays then the strength is sacrificed. Why is that? One reasons maybe the low income. And another important reason is that teachers can't really enjoy the pleasure of leisure. For example, many leisure ways like self-help travelling, scuba diving, rafting, snorkeling, ski and so on which need skills that is not every teacher has. So the balance of work and life is broken, teachers become busy like other jobs in China.

The ideas of job strength are put forward not very long time ago, so subsequent empirical and case studies are encouraged.

\section{Stretching Zone of AdVEnture AND Job Thriving}

To achieve job thriving and overcome burnout, employee should take adventure activities. John Medina suggests that human are born explorer, and the engine for adventure is the strong desire and endless curiosity to understand the world when we are born, which drives us to explore the surrounding 
world [8]. The adventure could be in our studies, for example, learning a new language, study on an unfamiliar major or field. And it could be in our work, for example, using a new method to finish old task, managing from control to incentive perspective etc. Also the adventure could be in our lives, like tasting a never eat food, listening a different style music, choosing a new way to a familiar place.

From adventure perspective, there are three areas in our lives and work: comfort zone, stretching zone and panic zone. Comfort zone is the main area in which we live and work. Because of accustomed to and familiar with this zone, staying here is very comfortable, and there is no any risk and accident here, work and live go on step by step. But staying in comfort zone for long time will cause sluggishness and burnout because of higher and higher repeatability in our lives and work. Panic zone means we are forced to confront challenges or tasks which are beyond our bear range, for example, a new employee or intern is offered a leader position and this will throw them into confusion because they are quite incompetent to do the work. Stretching zone is between the comfort zone and panic zone. After we cope with the challenges in stretching zone, it will improve our sense of achievement and conquest, and self-efficacy also is promoted. When we constantly set stretching zone activities step by step for ourselves and finish task in each stage, our self-efficacy will be strengthened, and we will stay away from job burnout Of course, everyone has quite different comfort, stretching and panic zones. For example, this is my first time to attend an international conference (the ICEBM-Sydney), so I have to try many things new which I have never done before. Likewise, I should express my ideas in English and pass the review of experts from the conference; I must apply for the funding from my university which requires many document materials to obtain administrative approval; also I should book the airplane and hotel etc. So, this conference is a stretching zone activity for me, but for many other professors who frequently attend international conference, it may be just comfort zone.

\section{HAMBURGER MODEL AND JOB THRIVING}

At last, to achieve job thriving and overcome burnout, people need to change their value about the work. Someone work hard just for the paycheck, some for a cause, and some regard job as a calling. Obviously, you couldn't count on a person who just works for money keeping positive attitude without promotion or salary increase. For those employees, the burnout is almost unavoidable especially when they have worked for many years. Comparably, those who work for a calling have stronger internal motivation and keep positive attitude towards their jobs.

Tal-Ben shahar suggests a hamburger model to summarize people's life style which includes four types [9]. Different types of life have quite different job values, and bring different results. Of course, no one is completely belonged to some type of life style, and the hamburger model just supplies a reference and reflection. The first type is called 'busy person' who sacrifices current happiness and benefit in order to succeed in the future. This type of person couldn't enjoy the joy in the present in life, and their life and work are just for the sake of goal attainment. Because the society only praise and honor the successful person, but who is in the process of trying. So the outside social evaluation system controls many people's motivation for work and life. This type of person rarely enjoys their work and their motto is "no pains, no gains". The second type is called 'hedonist' who is always looking for happiness and avoiding pain. They just want to fulfill current needs and never think about the outcome and future. They believe joy is equal to the happiness and hard work means pain. They always say "a happy heart every day is the most important". The hedonist meets no challenges at all in his lives and work, and avoids those things which might bring challenges because new challenge means new possible failure, frustration and anxiety. Professor Mihalyi Csikszentmihalyi dedicate his life to the study of peak experience and he thinks that man's best moments are always pursuing some goal and his strength play the incisively and vividly [10]. Obviously, the joy without effort and hard work is fleeting and not real happy. The third type is called nihilist who has given up the pursuit happiness and believed the life is no meaning. If the busy person lives and works for the future, the hedonist for now, and the nihilist for the past. They are immersed in the past, and no longer identify with job values and meanings. Job burnout means nothing in the work. The nihilist believes life and work are empty and no meaning. The fourth type is happiness person who believes the present and future benefit could be reconciled. For instance, Students who truly love learning derive present benefit from the pleasure they take in discovering new ideas and future benefit from the ways in which those ideas will prepare them for their careers. When we do the job which we really like, we could make progress when we enjoy our work.

\section{SUMMARY}

Through two surveys and one interview, this article discusses job burnout in Chinese public sector. Most studies on job burnout in Chinese public sector raise some vague solutions for the job burnout. This paper suggests job position design from external and job thriving in positive psychology perspective from internal to cope with the job burnout. The writer proposes some specific ways to overcome job burnout and realize job thriving which includes job vitality, job learning and job strength, stretching zone of adventure and hamburger model of job values etc.

Of course, more related empirical and case studies are needed and encouraged in the future.

\section{REFERENCES}

[1] L. E. Rumbley, I. F. Pacheco, and P. G. Altbach, International Comparison of Academic Salaries: An Exploratory Study, Boston College, Center for International Higher Education, Lynch School of Education, 2008.

[2] W. H. Wang, "Study on job burnout and countermeasure of Tianjin government employees," Master Dissertation, Tianjin University, 2008.

[3] H. X. Zhang and N. Cui, "Study on College Teachers' Job Burnout and Its Strategies," Journal of Tianjin Agricultural University, vol. 16, no. 3, September 2009. 
[4] X. H. Pan, "Study on nurse job burnout and organizational support," Master Dissertation, Fudan University, 2011.

[5] E. Lawler, "Motivation in work organizations," Jossey Bass Business and Management Series, Jossey-Bass, 1 edition, 2004.

[6] M. E. P. Seligman and M. Csikszentmihalyi, "Positive psychology," American Psychologist, vol. 55, pp. 5-14, 2000.

[7] G. Spreitzer, K. Sutcliffe, J. Dutton, S. Scott, and A. M. Grant, "A socially embedded model of thriving at work," Organizational Science, vol. 16 , no. 5 , pp. 537-550, 2005.

[8] J. Medina, Brain Rules: 12 Principles for Surviving and Thriving at Work, Home, and School, Pear Press, 2009.

[9] B. S. Tal, Happier: Finding Pleasure, Meaning and Life's Ultimate Currency, The Sagalyn Literary Agency, 2007.
[10] M. Csikszentmihalyi, Flow: The Psychology of Optimal Experience, simplified Chinese translation edition by China CITIC press, 2011.

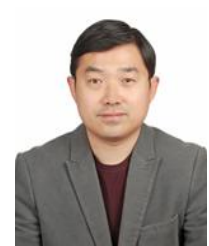

Hou Longlong is an associate professor in Beijing Normal University, his main research interests focus on positive organization behavior, application of positive psychology. 